\title{
La evaluación en la formación de formadores
}

\author{
Micaela Luz Lorenzotti ${ }^{(1)}$
}

Palabras clave. formación docente - didáctica de las disciplinas · evaluación · sistema educativo

Resumen. Este trabajo se centra en la instancia de evaluación de la formación de formadores. En los profesorados universitarios se evidencia una disociación en el programa de estudio: por un lado, el área de las materias llamadas "pedagógicas», espacios que problematizan diferentes aspectos de la formación del profesor y en los que los estudiantes se piensan como docentes; por otro lado, las materias llamadas «específicas», que problematizan el conocimiento sobre el objeto de estudio de la carrera en cuestión. En esta disociación, el fin último del aprendizaje del bagaje de contenidos, la futura enseñanza, queda al margen de las materias específicas/teóricas. La pregunta que intentamos responder es: ¿por qué y para qué evaluar los contenidos teóricos de cada disciplina en una posible situación de enseñanza concreta? Repensamos aquí la evaluación con la intención de delinear un camino hacia una nueva forma de evaluar en la formación de formadores, una forma que cruce la teoría con la práctica. Una forma de evaluar que considere a los contenidos teóricos enmarcados en situaciones de enseñanza de los futuros docentes.

\author{
Keywords. teachers formation - didactics \\ of discipline · evaluation · educative system
}

Abstract. This paperwork is focused on the evaluation instance of the educators' formation. In university profesorships a dissociation of the curriculum can be evidenced: by one way, the area of courses called «pedagogicals", which are to put in question different aspects of a professor formation and in which the students are consider like teachers; by another way, the "specific" courses that put in question the knowledge about the study object of the career in question. In this dissociation the ultimate goal of the learning of the baggage contents, the future teaching, is marginalizated from the specific/theoretical subjects. The question we are trying to answer is: why and for what evaluate the theoretical contents of each discipline in a possible situation of a specific teaching? Let rethink here the evaluation with the intention of feature a path to a new way of educators formation evaluation, a way that join the practical part with the theoretical one. A way of evaluating that consider the theoretical contents included in situations of teachings of the future teachers.

(1) IHUCSO UNL/CONICET lorenzottimicaela@gmail.com 